\title{
The Influence of Production Management Practices and Systems on Business Performance: From the Perspective of the Push-pull Production Systems
}

\author{
Hui-Ming Wee \\ Department of Industrial Engineering, Chung Yuan Christian University, Chungli, Taiwan \\ Email: weehm@cycu.edu.tw \\ Shu-Yun Peng \\ Department of Industrial Engineering, Chung Yuan Christian University, Chungli, Taiwan \\ Email: vicky@mis.cycu.edu.tw \\ Ching-Chow Yang \\ Department of Industrial Engineering, Chung Yuan Christian University, Chungli, Taiwan \\ Email: chinchow@cycu.edu.tw
}

Paul KP Wee

Department of Business, Division of Economic and Financial Studies, Macquarie University, Sydney, New South Wales, Australia

Email: awsomeping@gmail.com

\begin{abstract}
This study develops a conceptual model: Customer Output Process Integrated System (COPIS) with hybrid pushpull strategy. We seek to investigate the performance and critical success factors of a Taiwanese enterprise. The COPIS conceptual model provides managerial insights to enterprises to achieve their objectives as well as to improve customer relationship. Through an appropriate process design, the Taiwanese enterprise is able to control critical factors and performance indices to maintain flexibility and robustness. Enterprises should design and plan their process based on the characteristic of the business, the processing design, the flow design and the load leveling system.
\end{abstract}

Keywords: push-pull system, pull system, COPIS, production management

\section{Introduction}

The rapid globalization and booming technology have resulted in a challenging business environment (Toffler, 1990; Behrsin et al., 1994). Under this circumstance, business flexibility and adaptability become increasingly important (Ciborra, 1993). In order to gain competitive advantage over their competitors, organisations must be flexible, creative and innovative to adapt and response to changing external environments
(Wee et al, 2004). Specifically, markets driven by mass customization and e-commerce are forcing retailers and manufacturers to shorten their planning cycles, compress manufacturing lead times, and expedite distribution (Tyan et al., 2003). A competitive enterprise should have the ability to adapt better and faster to satisfy their customers (Childerhouse et al., 2002).

Enterprises must satisfy their customers by improving the speed of service, business flexibility 
and response capability. The push or pull production system is identified by the mechanisms for controlling material flow (Teeravaraprug and Stapholdecha, 2004). Push production system control strategies are based on forecasted customer demands. Its objective is to maximize the throughput of the system so as to minimize cost. On the other hand, pull production system control strategies are based on actual customer demands. They are considered to be reactive-oriented (Geraghty and Heavey, 2005). Hoverver, most production systems in practice may consist of both push and pull systems. A push/pull integration strategy is denoted by a hybrid production system (Hodgson and Wang, 1991a; 1991b). This means that some parts of the system are push while the others are pull.

The advantages and disadvantages of push and pull production systems have been discussed in literatures (Lee, 1989; Deleersnyder et al., 1992; Spearman and Zazanis, 1992). The production lead time and batch sizes affect the inventory undulations under a pull production system, while the degree of forecasting errors are the main concern in the push production system (Kimura and Terada, 1981). Furthermore, pull systems reduce inventory costs but do not respond well to unexpected changes in demand (Browne et al., 1988). The performance of pull systems and their variations are better suited for original equipment manufacturers (OEMs) (Spearman and Zazanis, 1992). MRP-type (Material requirements planning) push strategies have better performance in inventories and service for multiproduct system (Krishnamurthy et al., 2004). Hybrid strategy decreases inventory over the Kanban policy while maintaining the same service levels (Bonvik et al., 1997). Recently, several studies have compared the performances of push, pull and hybrid system by simulation (Bonvik et al., 1997; Bonney et al., 1999; Corry and Kozan, 2004; Teeravaraprug and Stapholdecha, 2004; Geraghty and Heavey, 2005). They concluded that the hybrid production system outperforms both the push and the pull strategies. This study uses an empirical method to investigate the condition and critical success factors of production management system. We construct a conceptual model and a set of questionnaire to investigate and compare the process design and control mechanisms among push, pull and hybrid production systems.

\section{Literature Review}

Production management systems are classified into push production systems (such as Material Requirement Planning, MRP) and pull production systems (such as Lean Production System, LPS) (Deleersnyder et al., 1992; Spearman and Zazanis, 1992; Bonney et al., 1999). The distinction between push and pull system is on how production orders are released to work stations in response to demands (Krishnamurthy et al., 2004). The push method is initiated based on the estimates of future demand and is controlled by a master production schedule. Most of the traditional management systems belong to the push process (Teeravaraprug and Stapholdecha, 2004). The main concern in the push system is the forecast errors (Kimura and Terada, 1981). In contrast, the pull method is initiated in response to current demand. The Just in time (JIT) manufacturing philosophy and Kanban-control system of the pull systems have been studied and implemented by many companies and academia around the world since Sugimori wrote the first article by on the Toyota production system in 1977 (Ou and Jiang, 1997).

According to Fiegenbaum and Thomas (1990), time is the real resource that enterprises should carefully utilize. Any enterprises that can response faster than the others will maintain certain advantages over its competitors. George (1994) suggested that all processes should be driven by customer requirements. Suri (1998) claimed that pull policies produce distinct demands in small batches. Most manufacturing systems improvements emphasize on achieving Lean Production System (LPS) (Duggan, 1998). The enterprise with the lowest lead time and highest quality will be the most competitive one. Based on the quantity of each order and shrinking variance, the LPS (also called Toyota Production System, TPS) have improved the processes of many enterprises. The essence of LPS is to eliminate unnecessary stock through a pull manufacture process design and shortened the cycle time of manufacturing. This will enable an enterprise to respond quickly. Automation (Jidoka) and JIT are crucial for efficient LPS (Womack and Jones, 2003). LPS contributes to reduce inventory, space requirements and costs through JIT techniques, shortening process distances and the elimination of non-value-added activities (Heizer and Render, 
2001). It will also shorten the throughput time of manufacturing. Pull production control strategies are based on actual customer demands at the end of the line; they are considered to be reactive-oriented (Geraghty and Heavey, 2005). LPS produces the right products in the right time (Miltenburg, 1989).

More practical system may consist of both the push and the pull systems, commonly called a hybrid production system (Hodgson and Wang, 1991a; 1991b). A hybrid system implies that some parts of the system are push strategy while the others are pull strategy. Each production system has advantages and disadvantages (Spearman and Zazanis, 1992). Therefore, this research integrates the MRP-type push production system and the LPS-type pull production system to construct a conceptual hybrid push-pull model. Base on the conceptual hybrid push-pull model, we construct a set of questionnaire to investigate and compare production management issues and control mechanisms in Taiwanese enterprises. This comparative analysis can help enterprises find critical success factors in production management and design for achieving their business objectives.

\section{Conceptual Model}

This study applies empirical research results to compare the different control mechanisms and performance ascent among pull, push and hybrid push-pull production systems. Our aim is to identify those key factors and critical success factors which can elevate business performance.

\subsection{Conceptual Hybrid Push-pull Model}

The hybrid production system outperforms both the push and the pull strategies (Corry and Kozan, 2004; Teeravaraprug and Stapholdecha, 2004; Geraghty and Heavey, 2005). This study integrates the "push" and "pull" production system to construct to construct a conceptual model of Hybrid push-pull COPIS (Customer Output Process Integrated System) as shown in Figure 1.

A successful company has five important asset categories including: physical assets, financial assets, employee \& supplier assets, customer assets, and organization assets. Furthermore, employee \& supplier assets, customer assets and organization assets play a crucial part in creating value for businesses (Libert et al., 2000). All processes should be driven by customer requirements (George, 1994). Thus the COPIS model aims at "Customer Relationship Management" (C) which starts at identifying customer perceived quality to fulfill customer requirements. The companies then focus on customer value to clarify customer expectations and requirements. All the enterprise activities output (O) are designed and driven by customer requirements to satisfy customers. Enterprises have to improve the value-added and the design processes of products and services efficiently. Therefore flexible capabilities and outsourcing are seen as an important element to accomplish this (Kremic et al., 2006). The flexible production management (P) of COPIS model integrates MRP-type push production system and LPS-type pull production system. It utilizes Jidoka and JIT. Positive changes in employee behaviors lead to positive results in customer satisfaction. What happens to employees inside the firm should affect what happens to customers outside the company (Hallowell et al., 1996; Chien et al., 2002).

The working conception of COPIS is integrating SCM \& DCM through suitable integrated information systems (Integrated System; IS) that share information with suppliers in the production planning. A way to reduce uncertainty in supply chain is to collaborate with the suppliers (Van der Vorst et al., 2002). The major issues of SCM implementation are outsourcing, logistics, partnerships and environment (Varma et al., 2006). Collaboration and outsourcing have become a mega trend in SCM (Feeney et al., 2005) which focuses on joint planning, coordination and process integration between the suppliers and the customers. Suitable outsourcing decisions can result in lower costs and competitive advantage (Cross, 1995). Therefore the upstream issue of COPIS is "supplier management" which includes three issues: supplier evaluation, supplier guidance \& assistance, and business partner. Enterprises should carefully analyze the customer oriented value chain and deploy tangible/ intangible assets to design the process.

The conceptual model of Hybrid push-pull COPIS is a customer oriented design which can help manager draw a conceptual outline. All activities in this model are triggered by customer requirement in the push-pull system. This conceptual model aims 
Figure 1. The conceptual model of Hybrid push-pull COPIS

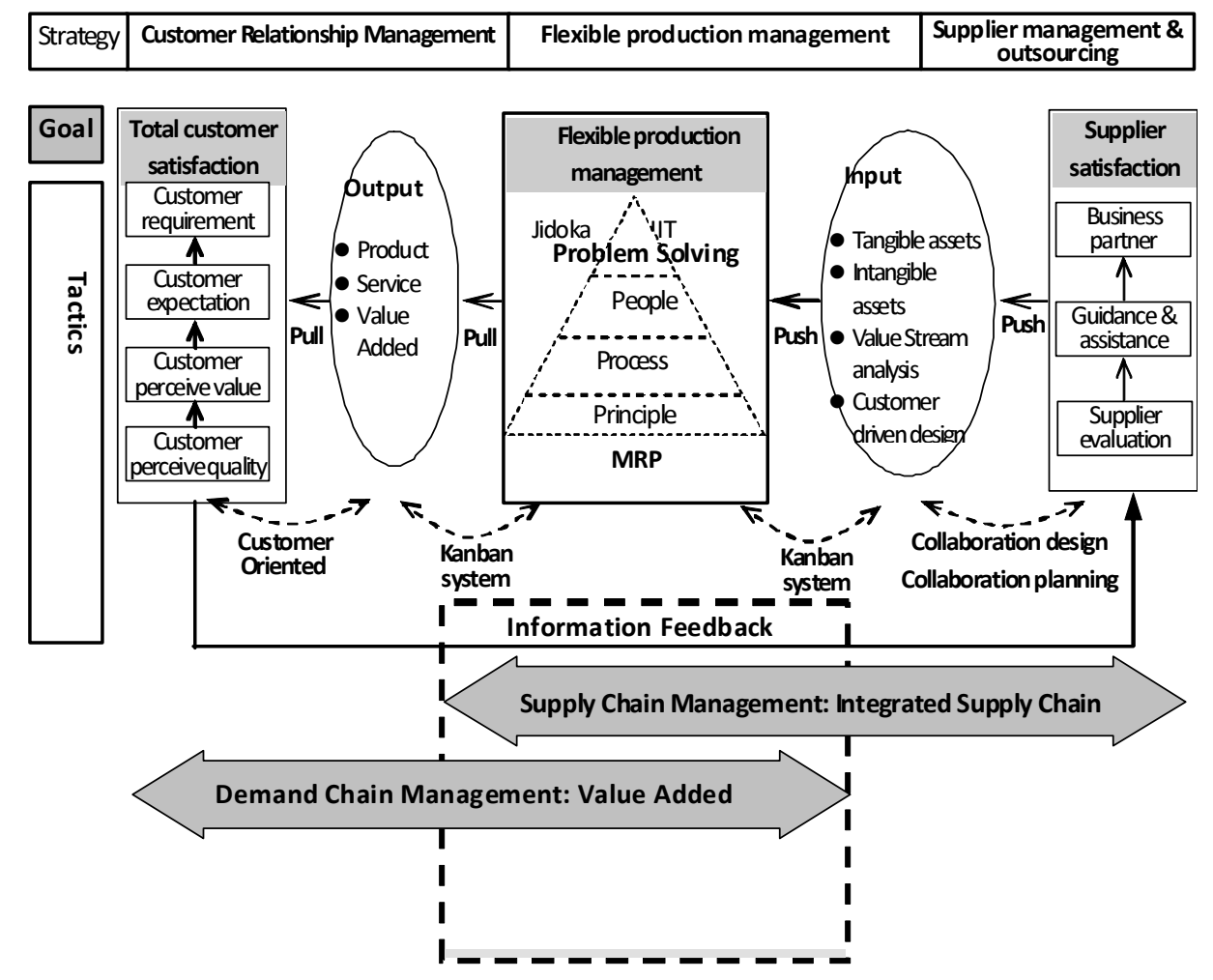

\begin{tabular}{|c|c|c|c|c|}
\hline Phase & Customer (Performance Upgrading) & Output (Performance Upgrading) & Process (Implementation) & Input-Supplier (Implementation) \\
\hline 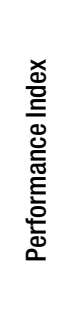 & $\begin{array}{l}\text { - Fulfilling customer need } \\
\text { - Customer satisfaction } \\
\text { - Customer complain }\end{array}$ & $\begin{array}{l}\text { - Fulfilling customer need } \\
\text { - Quality relative } \\
\text { - Cost relative } \\
\text { - Delivery relative } \\
\text { - Flexible capability relative } \\
\text { - Sales relative } \\
\text { - Speed relative } \\
\text { - Security relative } \\
\text { - Employee complain relative }\end{array}$ & $\begin{array}{l}\text { - Principle } \\
\text { - Process } \\
\text { - People \& Partners } \\
\text { - Problem Solving } \\
\text { - Supplier Management } \\
\text { - Production management systems } \\
\quad \text { \& techniques }\end{array}$ & $\begin{array}{l}\text { - Supplier satisfaction } \\
\text { - Supplier capability } \\
\text { - Supplier management system } \\
\text { - Supplier guidance \& assistance } \\
\text { - Supplier evaluation }\end{array}$ \\
\hline
\end{tabular}

to integrate the supply chain and the value-added in order to optimize the process management. Through the COPIS conceptual model and performance indicators which are linked to specific processes or activities, the enterprise is able to control critical factors and performance indices to maintain flexibility within each process. The COPIS conceptual model will help enterprises to achieve their objectives as well as improving the customer relationship.

\subsection{Methodology}

Based on the conceptual model of Hybrid push-pull COPIS, we construct a set of questionnaire. The critical perspectives come from literatures' inference and the specifics are according to the process with the " $4 \mathrm{P}$ " principle of TPS as well as 14 management principles (Liker, 2004). Then we consider the performance indicators for the critical perspectives by interviewing 10 senior managers who are 
responsible to the production or supplier management. Then, we draw some inferences and performance indicators to design the questionnaire. The questionnaire consists of three sections:

(1) Production management principle (six questions), process (thirty four questions), people \& partners (twelve questions), problem solving (twenty six questions) and supplier management (fourteen questions).

(2) Performance upgrading (twenty three questions)

(3) Information of enterprises (eleven questions)

The study analyses 203 subjects to compare the implementation of the production management. The questions use the 5-point Likert-scale ranging from 1 = "extremely low" to 5 = "extremely high". We investigate the application and compare the differences among push, pull and hybrid push-pull production systems using the above questions.

\subsection{Background of Participants and Reliability}

This empirical research collected data from nonToyota system enterprises thorough the helping of three Science Park Administrations locating in northern, central and southern Taiwan. We focused on semiconductors, aviation, precision machinery, optoelectronics, and conventional industries. We send questionnaires by mail, e-mail followed by phone calls and interview. A total number of 700 questionnaires were sent. A total of 238 questionnaires were returned (a response rate of $34 \%$ ). Out of the received mails, $85.3 \%$ was valid (203 out of 238). As shown in Figure 2, a quarter of the enterprises surveyed are electrical \& electronic industrial, $18 \%$ (36) are machinery \& metal

Figure 2. Sample sizes of different industrial groups

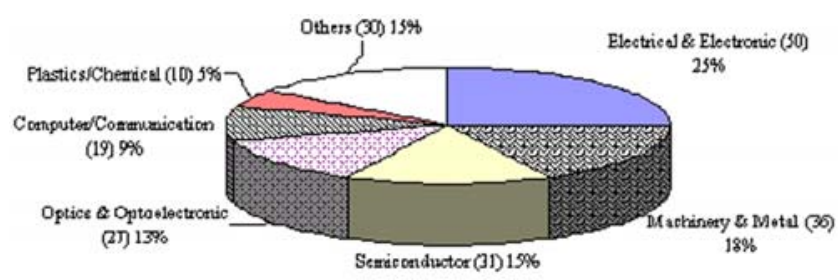

industrial and $15 \%$ (31) are semiconductor industrial. The range of their capital varies from less than 3 million to more than 1,500 million US dollars, $25.6 \%$ of the enterprises has a capital less than 3 million US dollars. The numbers of hired personnel also varies from less than 100 to more than 5,000 employees and $21.2 \%$ of them has 200 to 500 employees. For more details, please see Appendix A. Since the sample units include not only the prime industries but other classes of market capitalization as well, the bias is less likely to exist.

Table 1 shows the participants of different production system in different industrial groups. About $47.2 \%$ (17out of 36 ) of the machinery \& metal industry applies hybrid push-pull production system and $33.3 \%$ (12 out of 36 ) of them applies pull production system (see Table 1). About $42.1 \%$ (8 out of 19) of the computer/communication industry applies hybrid push-pull or push production system, only $15.8 \%$ (3 out of 19) of them applies pull production system. The percentages of three type's production systems are approximated.

Cronbach's $\alpha$ coefficient is used to determine the consistency on the reliabilities analysis (Cronbach, 1951). Cuieford (1965) later applied Cronbach $\alpha$ coefficient to represent the reliability of instrument. A lower $\alpha$ coefficient means the survey doesn't have enough consistency. On the other hand, a higher $\alpha$ coefficient shows the information is consistent (Churchill, 1979). The value of Cronbach $\alpha$ should be greater than 0.7 (Cuieford, 1965; DeVellis, 1991). We calculate the Cronbach $\alpha$ coefficient in our study to check the consistency, correlation, homogeneous, and reliability of our questionnaires. The overall Cronbach \pm lies between 0.7853 0.9668 and therefore has acceptable reliability.

\section{Comparison and Analysis of the Production Management}

\subsection{Implementation of Production Management}

The implementation of production management was analyzed differently using a one-way analysis of variance (ANOVA) with the least-squares difference (LSD) method. All calculations and statistics were carried out using SPSS10.0.7C for Windows. 
Table 1. Sample size of different production system in different industrial groups

\begin{tabular}{|l|c|r|r|r|r|}
\hline \multicolumn{1}{|c|}{ Production System } & & Hybrid $(\mathbf{n}=\mathbf{7 2})$ & Pull $(\mathbf{n}=\mathbf{6 1})$ & Push $(\mathbf{n}=\mathbf{7 0})$ & Total \\
\hline Electrical \& Electronic & $\mathrm{n}$ & 18 & 14 & 18 & 50 \\
& $\%$ & 36.0 & 28.0 & 36.0 & 100 \\
Machinery \& Metal & $\mathrm{n}$ & 17 & 12 & 7 & 36 \\
& $\%$ & 47.2 & 33.3 & 19.4 & 100 \\
Semiconductor & $\mathrm{n}$ & 10 & 9 & 12 & 31 \\
Optics \& Optoelectronic & $\%$ & 32.3 & 29.0 & 38.7 & 100 \\
& $\mathrm{n}$ & 8 & 8 & 11 & 27 \\
Computer/Communication & $\%$ & 29.6 & 29.6 & 40.7 & 100 \\
& $\mathrm{n}$ & 8 & 3 & 8 & 19 \\
Plastics/Chemical & $\%$ & 42.1 & 15.8 & 42.1 & 100 \\
Others & $\mathrm{n}$ & 3 & 4 & 3 & 10 \\
& $\%$ & 30.0 & 40.0 & 30.0 & 100 \\
\hline Total & $\mathrm{n}$ & 8 & 11 & 11 & 30 \\
& $\%$ & 26.7 & 36.7 & 36.7 & 100 \\
\hline
\end{tabular}

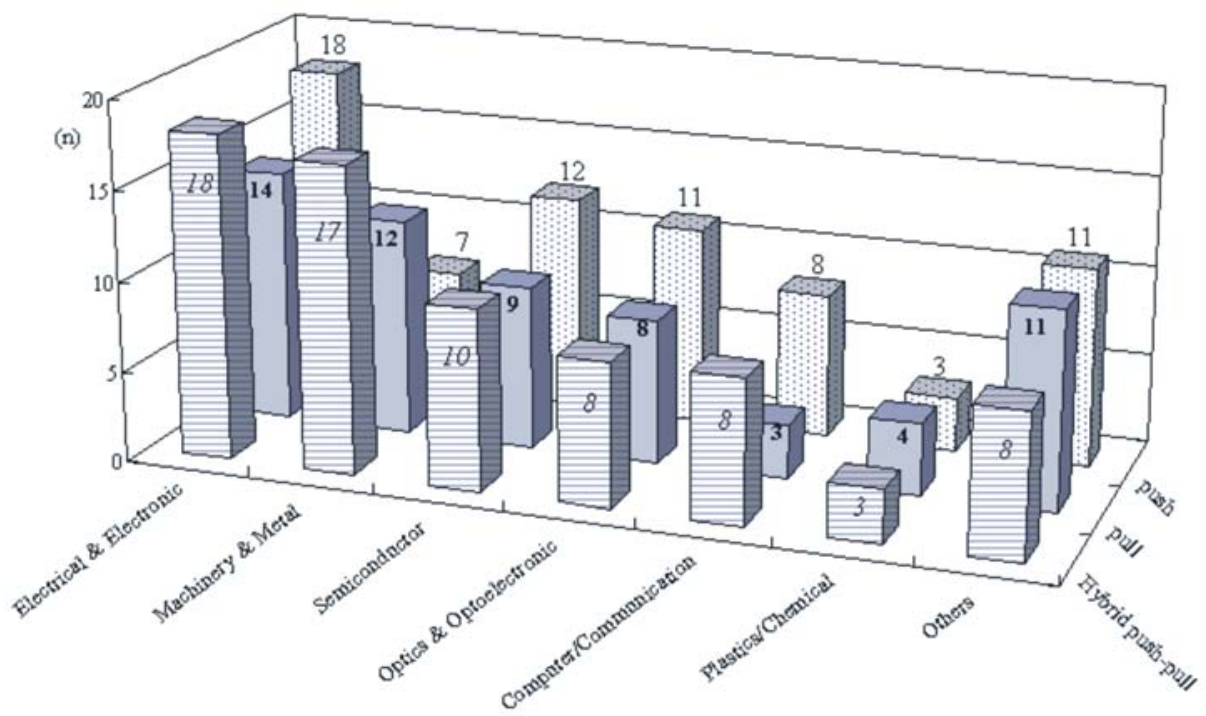

Table 2(a). Implementation ANOVA of production management

\begin{tabular}{|c|c|c|c|c|c|c|c|c|}
\hline \multirow{2}{*}{ Construct Variable } & \multicolumn{2}{|c|}{ Hybrid (n=72) } & \multicolumn{2}{|c|}{ Pull (n=61) } & \multicolumn{2}{|c|}{ Push $(n=70)$} & \multirow{2}{*}{$F$} & \multirow{2}{*}{$P$} \\
\hline & $\overline{\mathrm{x}}$ & SD & $\overline{\mathrm{x}}$ & SD & $\overline{\mathrm{x}}$ & SD & & \\
\hline I. Production Management & 3.947 & 0.462 & 3.989 & 0.515 & 3.813 & 0.505 & 2.339 & 0.099 \\
\hline (1) Principle & 4.005 & 0.649 & 3.959 & 0.606 & 3.898 & 0.643 & 0.508 & 0.603 \\
\hline (2) Process & 3.981 & 0.508 & 3.954 & 0.543 & 3.853 & 0.533 & 1.146 & 0.32 \\
\hline (3) People \& partners & 3.993 & 0.595 & 4.007 & 0.654 & 3.951 & 0.664 & 0.139 & 0.870 \\
\hline (4) Problem solving & 3.862 & 0.600 & 3.996 & 0.567 & 3.707 & 0.640 & 3.734 & $0.026^{*}$ \\
\hline (5) Supplier management & 3.893 & 0.495 & 4.029 & 0.585 & 3.654 & 0.703 & 6.634 & $0.002^{*}$ \\
\hline
\end{tabular}


Table 2(b). LSD post-hoc test results of production management

\begin{tabular}{|l|c|c|c|c|}
\hline \multirow{2}{*}{$\begin{array}{c}\text { Construct } \\
\text { Variable }\end{array}$} & \multicolumn{2}{|c|}{ Problem Solving } & \multicolumn{2}{c|}{ Supplier Management } \\
\cline { 2 - 5 } & Hybrid & Pull & Hybrid & Pull \\
\hline Push & 0.129 & $\begin{array}{c}\text { (Push }<\text { Pull) } \\
p=0.007^{*}\end{array}$ & $\begin{array}{c}\text { (Push }<\text { Hybrid) } \\
p=0.000^{* *}\end{array}$ & $\begin{array}{c}\text { (Push }<\text { Pull) } \\
p=0.019^{*}\end{array}$ \\
Pull & 0.205 & - & 0.193 & - \\
\hline
\end{tabular}

The production management has no significant differences ( $\mathrm{F}=2.339 ; \mathrm{p}=0.099)$ among push, pull and hybrid push-pull production systems. As for construct variables, significant differences have been found in the problem solving $(\mathrm{F}=3.734 ; \mathrm{p}=0.026)$ and supplier management $(\mathrm{F}=6.634 ; \mathrm{p}=0.002)$ as shown in Table 2(a). But there are no significant differences in principle $(\mathrm{F}=0.508 ; \mathrm{p}=0.603)$, process $(\mathrm{F}=1.146$; $\mathrm{p}=0.32)$ and people \& partners $(\mathrm{F}=0.139 ; \mathrm{p}=0.87)$. Table 2(b) shows LSD post-hoc test results of significant variables.
Significant differences have been found in the problem solving between "push" and "pull" production system $(\mathrm{p}=0.007)$, but no significant differences have been found between "hybrid" and "pull" production system ( $\mathrm{p}=0.205)$. Those enterprises which apply a pull production system implement "problem solving" better than the enterprise applying push production system. This implies that pull production system will pay more attention to problem solving. Significant differences have been found in the supplier management between "hybrid" and "push" production system ( $\mathrm{p}=0.000)$, as well as between "pull" and "push" production system $(p=0.019)$. Those enterprises which apply a pull/ hybrid pull production system have higher administration of supplier management than with a push production system. But no significant differences have been found in the supplier management between "hybrid" and "pull" production system $(p=0.193)$. This implies that the

Table 3. Process management application (1)

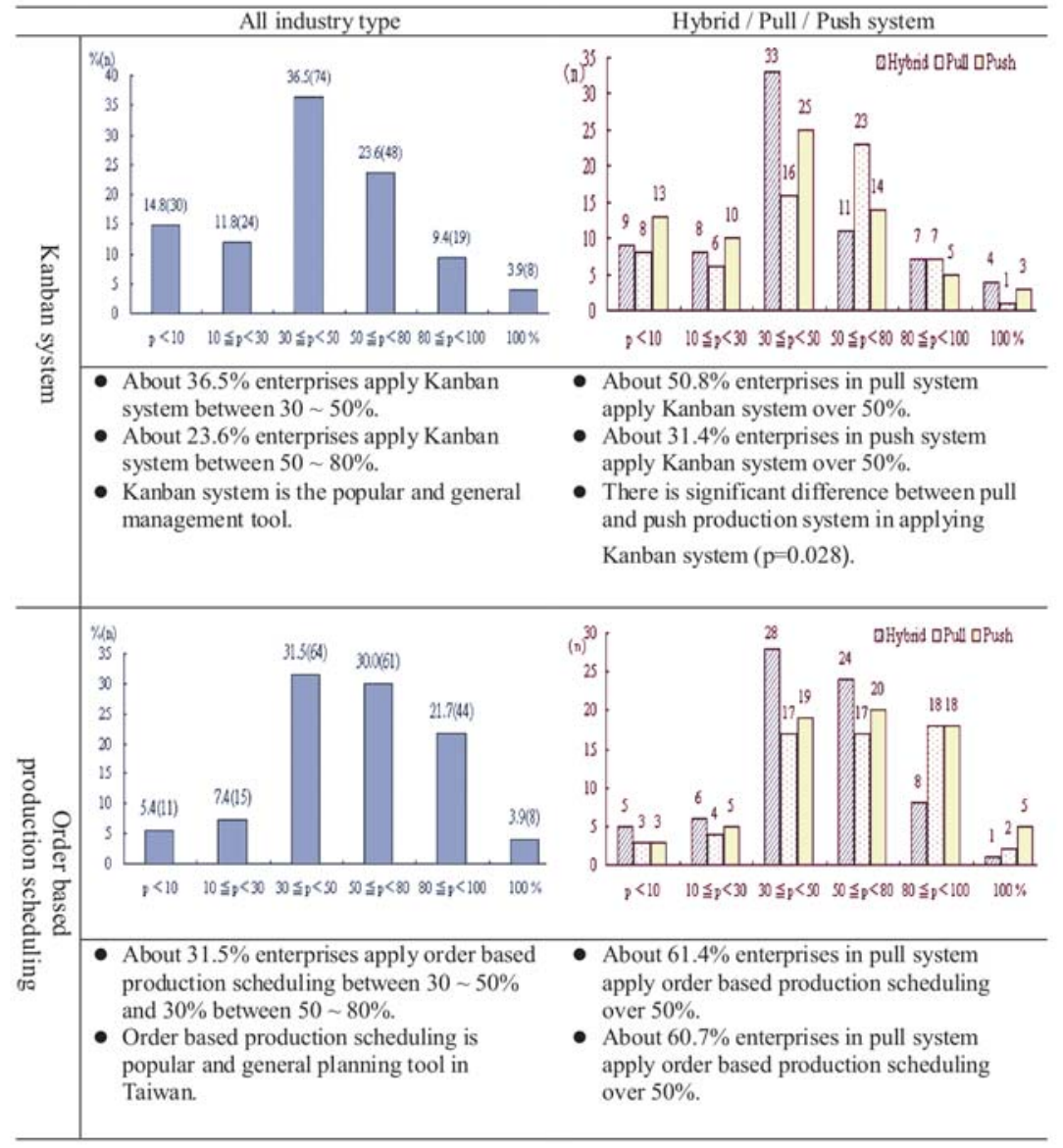


Table 4. Process management application (2)

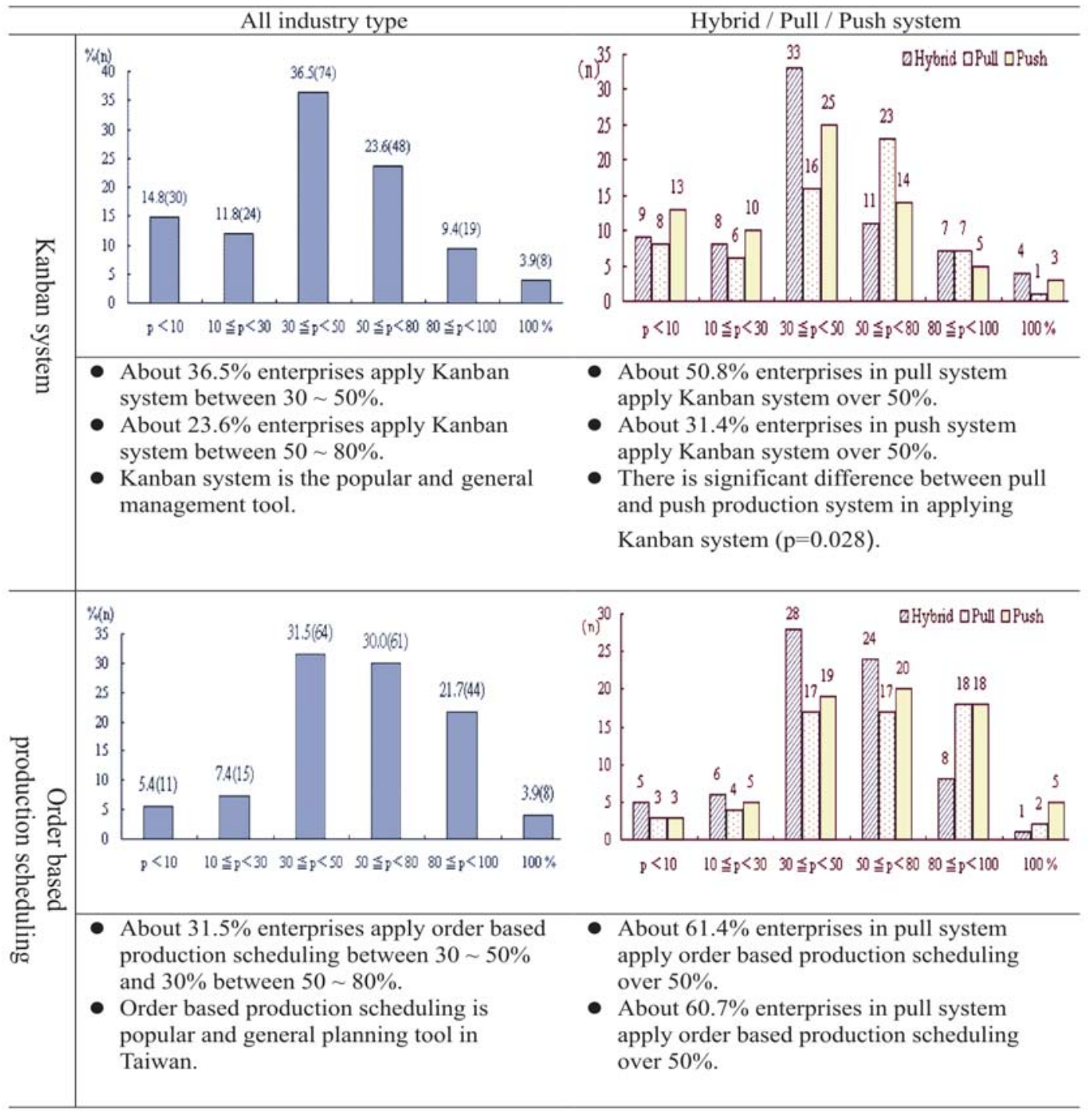

enterprises which formally introduce LPS will place more emphasis on supplier management for production management.

\subsection{Process Management Application}

The study analyses 203 of the process management application in four perspectives: "Kanban system", "Order based production scheduling", "One-piece flow design" and "Load leveling system". The result is shown in Table 3, Table 4 and listed in more detail in Appendix B.
No significant difference is found in applying order based production scheduling. Since most Taiwanese enterprises are OEM/ODM, they fulfill orders by ordering based production scheduling.

The survey shows that these two LPS-style manufacturing process designs are highly practical. The enterprises which apply pull production system have better application range than those of push production system. This also implies that the enterprises which formally introduce LPS emphasize more on the importance of load leveling schedule for process management application. 


\section{Critical Success Factors in Production Management}

\subsection{Performance Upgrading}

Sixteen questions have been found significant in production management. They are classified into five phase in this section. This analysis tests the significant improvement between hybrid push-pull, pull and push production system. Table 5 shows the significant results of each pair.

There are significant differences between push and pull production system in quality improvement $(\mathrm{t}=3.065, \mathrm{p}=0.003)$, cost improvement $(\mathrm{t}=2.505, \mathrm{p}=$ $0.013)$ and flexibly $(t=2.626, p=0.010)$. Significant differences are found between either pull and hybrid push-pull production system $(t=2.341, p=0.021)$ or push and pull production system $(t=3.276, p=0.001)$.
As regards the customer satisfaction, both integrated and pull production systems are better than push production system. We can conclude that those companies applying pull and hybrid push-pull production systems result in better performance than push production system.

\subsection{The Regression Analysis of Key Factors}

Based on how management performances influences the customer satisfaction, we assume a linear relation between customer satisfaction and the nine factors (on time delivery, $X_{1}$; quality improvement, $X_{2}$; fulfilling customer need, $X_{3}$; product changing flexibly, $X_{4}$; lower stock cost, $X_{5}$; shorten delivery time, $X_{6}$; quick $R \& D, X_{7}$; flexible capability, $X_{8}$ and shorten R\&D lead time, $X_{9}$ ). After

Table 5. Significant differences of performance upgrading

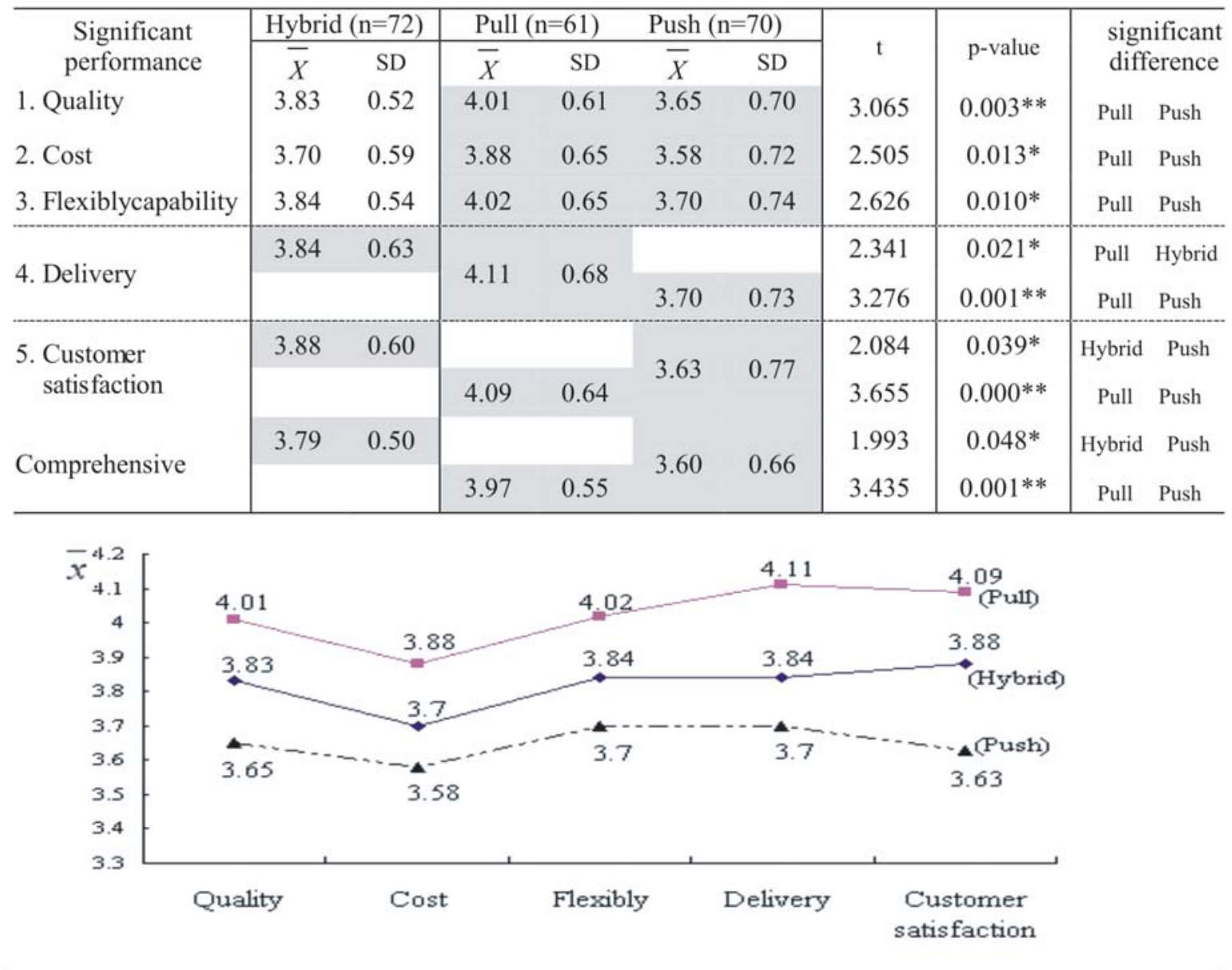


Table 6. Regression analysis of customer satisfaction

\begin{tabular}{lrrrrl}
\hline \multicolumn{1}{c}{ Model } & \multicolumn{1}{c}{ SS } & df & \multicolumn{1}{c}{ MS } & F & p-value \\
\hline Regression & 2150.519 & 5 & 430.104 & 2003.298 & $0.000^{* *}$ \\
Residual & 27.481 & 128 & 0.215 & & \\
Total & 2178.00 & 133 \\
\hline$R=0.994$, & $R^{2}=0.987$, & Adj $R^{2}=0.987$ \\
\hline \multicolumn{7}{c}{ Coefficients } \\
\multicolumn{7}{c}{ Variable } & \multicolumn{1}{c}{ Std. Error } & $\mathrm{t}$ & $\mathrm{p}$-value \\
\hline On time delivery, $X_{1}$ & 0.232 & 0.233 & 3.648 & $0.000^{* *}$ \\
Quality improvement, $X_{2}$ & 0.209 & 0.207 & 3.181 & $0.002^{* *}$ \\
Fulfilling customer need, $X_{3}$ & 0.202 & 0.203 & 2.800 & $0.006^{* *}$ \\
Product changing flexibly, $X_{4}$ & 0.194 & 0.192 & 2.623 & $0.010^{* *}$ \\
Lower stock cost, $X_{5}$ & 0.174 & 0.165 & 2.855 & $0.005^{* *}$ \\
\hline
\end{tabular}

the first and the second regression analysis and eliminating the insignificant factors, we keep five significant performances, as shown in Table 6 .

Since $R^{2}=0.987$, the formula below shows $98.7 \%$ of the customer satisfaction $(Y)$ :

$Y=0.232 \times X_{1}+0.209 \times X_{2}+0.202 X_{3}+0.194 \times X_{4}+0.174 \times X_{5}$

On time delivery and quality are the key factors that effect customer satisfaction. Other crucial factors are fulfilling customer need, flexibly and lower stock cost. These results provide managerial insights to industry in production management.

\section{Discussion and Conclusions}

In order to test and verify the conceptual model of the hybrid push-pull COPIS system, our study selected only those non-Toyota system enterprises. Based on our analysis of 203 valid questionnaires, we show that hybrid push-pull and pull production system perform better. The significant factors in the production management include: quality improvement, cost improvement, flexibly and on time delivery. Both hybrid push-pull and pull production systems result in a higher customer satisfaction than the push production system. Spearman and Zazanis (1992) concluded that the performance of pull systems is better suited for OEMs. According to our investigated, no significant difference is found in applying orders based on production scheduling among push, pull and hybrid production systems, since most Taiwanese enterprises are OEM/ODM.

We also show that a good customer relationship is very important in the hybrid push-pull or pull production systems. "On time delivery" and "quality" are the top 2 key factors affecting customer satisfaction. The customer satisfaction regression equation [1] shows that in order to achieve a better customer relationship, an enterprise must provide delivery on time, offer good quality products, product flexibly and efficient stock control. This gives managerial insights to enterprises in what to focus. Future researches can be done to compare the relationship between the Toyota system enterprises and the non- Toyota system enterprises.

\section{References}

Behrsin, M., Mason, G., and Sharpe, T. (1994). Reshaping IT for business flexibility. London: McGraw-Hill.

Bonney, M.C., Zhang, Z., Head, M.A., Tien, C.C. and Barson, R.J. (1999). Are push and pull systems really so different? International Journal of Production Economics 59, pp. 53-64. 
Bonvik, A.M., Couch, C.E., and Shwin, S.B.G. (1997). A comparison of production-line control mechanisms. International Journal of Production Research 35(3), pp. 789-804.

Browne, J., Harhen, J. and Shivnan, J. (1988). Production management systems: A CIM perspective. AddisonWesley, Workingham.

Chien, T.K., Su, C.H., and Su, C.T. (2002). Implementation of a Customer Satisfaction Program: A case study, Industrial Management $\mathcal{E}$ Data System 102 (5/6), pp. 252-259.

Childerhouse, P., Aitken, J. and Towill, D.R. (2002). Analysis and design of focused demand chains. Journal of Operations Management 20(6), pp. 675-689.

Churchill, G.A. (1979). A paradigm for developing better measures of marketing constructs, Journal of Marketing Research 16, pp.64-73.

Ciborra, C.U. (1993). Teams, markets and systems. Cambridge: Cambridge University Press.

Corry, P. and Kozan, E. (2004). Mete-heuristics for a complex push-pull production system. Journal of Intelligent Manufacturing 15, pp. 381-393.

Cronbach, L.J. (1951). Coefficient alpha and the internal structure of tests. Psychometrika 16, pp. 297-334.

Cross, L. (1995). IT outsourcing: British Petroleum's competitive approach. Harvard Business Review 1, pp. 25-31.

Cuieford, J.P. (1965). Fundamental Statistics in Psychology and Education (4 $\left.{ }^{\text {nd }}\right)$. McGraw Hill.

Deleersnyder, J,L., Hodgson, T.J., King, R.E., O'Grady, P.J. and Savva, A. (1992). Integrating kaban type pull systems and MRP type push systems: Insights from a Markovian model. IEEE Transactions 24(3), pp. 4356.

DeVellis, R.F. (1991). Scale development: Theory and application. London: Sage Publication Inc.

Duggan, K.J. (1998). Facilities design for lean manufacturing. IIE Solutions 30(12), pp. 30-34.

Feeney, D., Lacity, M. and Wilcox, L.P. (2005). Taking the measure of outsourcing providers. Sloan management Review 46(3), pp. 41-48.

Fiegenbaum, A. \& Thomas, H. (1990). Strategic group and performance: The U.S. insurance industry. Strategic Management Journal 11(3), pp. 197-215

Geraghty, J. and Heavey, C. (2005). A review and comparison of hybrid and pull-type production control strategies. OR Spectrum 27, pp. 435-457.

George, S. (1994). Total Quality Management. New York: Wiley.

Hallowell, R., Schlesinger, L.A. and Zornitsky, J. (1996). Internal Service Quality, Customer and Job Satisfaction: Linkages and Implications for Management. Human Recourse Planning 19(2), pp. 2031.

Heizer, J. and Render, B. (2001). Operations Management $\left(6^{\text {nd }}\right)$. Upper Saddle River, New Jersey: Prentice-Hall, Incorporated.
Hodgson, T.J. and Wang, D. (1991a). Optimal hybrid push/ pull control strategies for a parallel multi-stage system: Part I. International Journal of Production Research 29(7), pp. 1279-1287.

Hodgson, T.J. and Wang, D. (1991b). Optimal hybrid push/ pull control strategies for a parallel multi-stage system: Part II. International Journal of Production Research 29(7), pp. 1453-1460.

Kimura, O. and Terada, H. (1981). Design and analysis of pull system, a multi-stage production control. International Journal of Production Research 19(3), pp. 241-253.

Kremic, T., Tukel, O.I. and Rom, W.O. (2006). Outsourcing decision support: a survey of benefits, risks, and decision factors. Supply Chain Management 11(6), pp. 467-482

Krishnamurthy, A., Suri, R. and Vernon, M. (2004). Reexamining the performance of MRP and Kanban material control strategies for multi-product flexible manufacturing system. The International Journal of Flexible Manufacturing Systems 16, pp. 123-150.

Lee, L.C. (1989). A comparative study of the push and pull production system. International Journal of Operations and Production Management 9(4), pp. 518.

Libert, B.D., Samek, S.M. and Boulton, R.E.S. (2000). Cracking the value code: How successful businesses are creating wealth in the new economic. Harper business.

Liker, J.K. (2004). The Toyota way: 14 management principles from the world's greatest manufacturer. McGraw-Hill.

Miltenburg, J. (1989). Levelschedules for mixed -model assembly lines in Just-In-Time production systems. Management Science, 35(2), pp. 192-207.

$\mathrm{Ou}, \mathrm{J}$. and Jiang, J. (1997). Yield comparison of push and pull control methods on production systems with unreliable machines. International Journal of Production Economics 50, pp. 1-12.

Spearman, M.L. and Zazanis, M.A. (1992). Push and pull production systems: Issues and comparisons. Operations Research 40(3), pp. 521-532.

Suri, R. (1998). Quick response manufacturing: A companywide approach to reducing lead time. Productivity Press, Portland, OR.

Teeravaraprug, J. and Stapholdecha, S. (2004). Performance analysis of push, pulls, and mixed systems. Thammasat International Journal of Science and Technology 9(4), pp. 29-36.

Toffler, A. (1990). Power shift. NY: Bantam Books.

Tyan, J.C., Wang, F.K. and Du., T.C. (2003). An evaluation of freight consolidation polices in global third party logistics. OMEGA 31, pp. 55-62.

Van der Vorst, J.G.A.J. and Beulens, A.J.M. (2002). Identifying sources of uncertainty to generate supply chain redesign strategies. International Journal of Physical Distribution $\mathcal{E}$ Logistics Management 32(6), pp. 409-430. 
Varma, S., Wadhwa, S. and Deshmukh, S.G. (2006). Implementing supply chain management in a firm: issues and remedies. Asia Pacific Journal of Marketing and Logistics 18(3), pp. 223-243.

Wee, P.K.P., Wang, C.E. and Wee, H.M. (2004). Business is not what it used to be...and never will be. Technology Forecasting and Social Change 72(5), pp. 641-644.
Womack, J.P. and Jones, D,T. (2003). Lean thinking: Banish waste and create wealth in your corporation $\left(2^{\text {nd }}\right)$. Simon \& Schuster Rockefeller Center.

Hui-Ming Wee is a Professor in Industrial \& Systems Engineering, Chung Yuan Christian University, Taiwan. His research interests are in the field of production/inventory control, optimization, creative-problem solving and supply chain management. He received his B.Sc (Hons) from the University of Strathclyde, UK, Master from Asian Institute of Technology (AIT) and Ph D from Cleveland State University, Ohio, USA. He has published widely and served on the Editorial board of Computers and Operations Research, Operations and Supply Chain Management, International Journal of Applied Decision Sciences, International Journal of Applied Management Science, International Journal of Data Analysis Techniques and Strategies and Journal of Advanced Engineering.

Shu-Yun Peng is a Lecturer of Industrial Engineering \& Management in Ching Yung University, Taiwan. She received her Ph D in Industrial \& Systems Engineering from Chung Yuan Christian University, Taiwan in 2008. Her research interests include management science, production management, quality management and human and computer interaction.

Ching-Chow Yang is a Professor of Industrial \& Systems Engineering in Chung Yuan Christian University, Taiwan. He received his Ph D in Management Science from the National Chian-Tung University, Taiwan. Dr. Yang was honoured with the Individual Award of the ROC National Quality Awards in 1977. His research interests include total quality management, strategy management, service quality and Six Sigma. He is a Senior Consultant for many famous companies in Taiwan and China.

Paul PK Wee has graduated from Macquarie University with a Master Degree in Commerce, focusing in Accounting and Finance. He has published in Technological Forecasting \& Social Change, Journal of Information $\mathcal{E}$ Optimization Sciences and International Transactions of Operational Research. Currently, he is on job transition. 
Wee et al: The Influence of Production Management Practices and Systems on Business Performance Operations \& Supply Chain Management 2 (1) pp 11-23 @ 2009

Appendix A: Background of Participants

\begin{tabular}{l|c|c|l|c|c|c|c|c}
\hline \multicolumn{4}{c|}{ INDUSTRIAL } & \multicolumn{3}{c|}{ CAPITAL (US) } & \multicolumn{3}{c}{ EMPLOYEE } \\
\hline & No. & $\%$ & & No. & $\%$ & & No. & $\%$ \\
\hline Electrical \& Electronic & 50 & 24.4 & $<3$ & 52 & 25.6 & $p<100$ & 41 & 20.2 \\
Machinery \& Metal & 36 & 17.3 & $3 \leq \$<15$ & 40 & 19.7 & $100 \leq p<200$ & 29 & 14.3 \\
Semiconductor & 31 & 14.2 & $15 \leq \$<30$ & 30 & 14.8 & $200 \leq p<500$ & 43 & 21.2 \\
Optics \& Optoelectronic & 27 & 13.4 & $30 \leq \$<150$ & 37 & 18.2 & $500 \leq p<1,000$ & 27 & 13.3 \\
Computer/Communication & 19 & 12.6 & $150 \leq \$<300$ & 12 & 5.9 & $1,000 \leq p<5,000$ & 40 & 19.7 \\
Plastics/Chemical & 10 & 3.1 & $300 \leq \$<1,500$ & 16 & 7.9 & $p g \geq 5,000$ & 23 & 11.3 \\
Others & 30 & 15.0 & $\$ \geq 1,500$ & 16 & 7.9 & & & 203 \\
\hline Total & $\mathbf{2 0 3}$ & 100 & Total & $\mathbf{2 0 3}$ & 100 & Total & 100 \\
\hline
\end{tabular}

Appendix B: Process management \& manufacturing process design application

\begin{tabular}{l|c|c|c|c|c|c|c|c}
\hline & \multicolumn{2}{|c|}{ Kanban System } & \multicolumn{2}{c|}{$\begin{array}{c}\text { Order based production } \\
\text { scheduling }\end{array}$} & \multicolumn{2}{c|}{ One-piece flow design } & \multicolumn{2}{c}{ Load leveling system } \\
\hline & No. & $\%$ & No. & $\%$ & No. & $\%$ & No. & $\%$ \\
\hline$<10 \%$ & 30 & 14.8 & 44 & 21.7 & 34 & 16.7 & 30 & 14.8 \\
$10 \leq \mathrm{p}<30 \%$ & 24 & 11.8 & 29 & 14.3 & 22 & 10.8 & 31 & 15.3 \\
$30 \leq \mathrm{p}<50 \%$ & 74 & 36.5 & 39 & 19.2 & 59 & 29.1 & 63 & 31.0 \\
$50 \leq \mathrm{p}<80 \%$ & 48 & 23.6 & 23 & 11.3 & 27 & 13.3 & 37 & 18.2 \\
$80 \leq \mathrm{p}<100 \%$ & 19 & 9.4 & 16 & 7.9 & 19 & 9.4 & 21 & 10.3 \\
$100 \%$ & 8 & 3.9 & 52 & 25.6 & 42 & 20.7 & 21 & 10.3 \\
\hline Total & 203 & 100 & 203 & 100 & $\mathbf{2 0 3}$ & 100 & $\mathbf{2 0 3}$ & 100 \\
\hline
\end{tabular}

